\title{
第161回 岡山外科会
}

\author{
日 時：平成18年 9 月 16 日（土） $13: 00$ \\ 場 所：岡山大学医学部臨床第 2 講義室 \\ 会 長：永 瀬 瑶 典
}

(平成18年11月 27 日受稿)

\section{C1/2 高位非骨傷性頚髄損傷の 1 例}

岡山赤十字病院 整形外科

岡田芳 樹, 東原信七郎, 梅原 憲 史

浅 海 浩二, 片岡昌樹, 高橋 雅也

小西池泰三，那 須 正 義

症例は33歳の男性. 交通事故にて受傷. ドクターヘリに て当院へ搬送され，来院時は不全四肢麻痺の状態で下顎部 や後頭部の異常知覚の訴えがあった。画像上，C $1 / 2$ 高位 非骨傷性䅡髄損傷の診断で，入院し保存的に経過を見てい た. 症状は徐々に改善し, 受傷後 4 週の時点で, 上肢と後 頭部の知覚障害と, 上肢の巧緻性障害を残すのみとなった。 C 1 / 2 高位の春髄損傷で三叉神経の障害も併発するとい うまれな症例を経験したので報告した。

\section{2. 術中 3D-CT を用いた整復位確認の有用性}

国立病院機構岡山医療センター 整形外科

西之原正昭，塩田直史，佐藤徹

荒㴰慎也，佐伯光崇

近年関節内骨折や，関節近傍の骨折においては，術前 3 DCT にて骨折部の転位や骨折型を判断することが必須 となりつつある。しかしながら, 症例によっては手術中に は単純透視下・直視下でも転位の程度がわかりにくい症例 が認められる.今回我々はそれらの症例に対し術中 3 DCT を行うことで，転位した骨折部の整復状況をより詳細に把 握することが可能であった。 また今までより小切開手術を 行うことができる可能性を見出したので報告する。

\section{3. 受傷後早期に肺塞栓症を発症した Suicidal Jumper's Fracture の一例}

岡山大学医学部 - 歯学部附属病院 整形外科

高畑智宏, 野田知之, 古松毅之

田中雅人, 中西一夫, 杉本佳久

尾崎敏文

上位仙骨の横骨折に仙骨両側の縦骨折を合併する複合骨 折は高所からの Jumpingにより生じ, Suicidal Jumper's
Fracture と呼ばれる稀な外傷である. 単純 X 線正面像, CT 水平断での診断は極めて困難で, 診断確定には MPR が有 用である. 今回, 本骨折に受傷後早期に無症候性肺塞栓症, 深部静脈血栓症を合併した一例を経験したので報告する。

\section{4.レット症候群に合併した側彎症の 1 例}

岡山大学医学部 · 歯学部附属病院 整形外科

門田康孝, 田中雅人, 中西一夫 杉本佳久，三澤治夫，㴰川朋亨 尾崎敏文

レット症候群は女児のみに発症する進行性神経疾患で, 手もみ運動や手の有目的運動の变失, てんかん発作, 側弯 を合併する事が特徴である。今回レット症候群に合併した 側彎症に手術を施行したので報告する.症例は16歳女児で, 側彎は Cobb 角 TH 5 L 2 で74で, TH 1 L 3 に対し て後方固定術を施行し, Cobb 角は $27^{\circ}$ 矯正された・レッ 卜症候群の患者の周術期では種種の合併症を生じやすく, 慎重な管理が必要である.

\section{5 . 長下肢ギプス固定後に肺塞栓 (PE) を発症した, 深部静脈血栓症（DVT）の一例}

岡山労災病院 整形外科

妹尾貴矢，篠田潤子，小見山貴充 難波良文, 有森勧, 花川志郎

膝蓋骨骨折に対しギプス固定後 PE を発症したDVTの 症例を経験したので報告する。症例61歳女性, 転倒し受傷, 長下肢ギプス固定. 約 2 週間後に呼吸苦出現. 低酸素血症, 心エコーで右心負荷, 造影 CT で PE 認めた為, 緊急に一 時的 IVC フィルターを挿入し血栓溶解療法開始. その後, 肺動脈血栓消失も左下肢血栓残存あり, 恒久的フィルター を挿入. 本症例より日常診療においても DVT を念頭に置 いた加療が必要と考える。 


\section{6. 腓腹皮弁を用いた下腿再建の 1 例}

岡山大学大学院医歯薬学総合研究科 形成再建外科学 安岡智之, 杉山成史, 平川久美子 中島美帆, 山下修二, 山田潔 筒 井 哲 也, 長谷川健二郎, 難波祐三郎 木股敬裕

近年, マイクロサージャリーの発達により四肢の再建に おける選択肢は広がってきている，しかし，血管吻合技術 の必要性や手術時間の延長などの問題点もある. 今回我々 は下方を茎とした腓腹皮弁を用い，下腿から足関節前面に かけての再建を行った。この皮弁は短時間で容易に挙上で き, 下腿の主要血管の犠牲もないため, 非常に有用な皮弁 であると思われた。

\section{7 . 気管支に多発性の小孔を認めた縦隔気腫の一例}

岡山大学医学部 $\cdot$ 歯学部附属病院 呼吸器外科

国宗和歌菜, 佐野由文, 平見有二 山根正修, 豊岡伸一, 青江 基

伊達洋至

気道に認めた小孔が原因と思われる縦隔気腫の 1 例を経 験したので報告する. 症例は20歳の男性. パソコン操作中 に突然前胸部圧迫感あり近医受診， CT にて縦隔気腫を指 摘され当院紹介入院となった。気管支鏡にて左主気管支膜 様部に小孔あり, 呼気時に閉塞し吸気時に開存するためこ れを責任病変と判断した。保存的に諸症状は軽快, CT 上 気腫も減少した。退院前の気管支鏡にて気管下部より左気 管支に至る多発性の小孔を確認し得た。

\section{8．気瘻部位が同定できなかった広範囲な外傷性縦隔 気腫の 1 例}

岡山大学大学院医歯薬学総合研究科 腫瘍・胸部外科学 奥谷大介, 青江 基, 山根正修 羽藤慎二, 豊岡伸一, 佐野由文 伊達洋至

症例：57歳男性. 右胸部外傷. 右多発胁骨骨折とともに 広範囲縦隔・皮下気腫を認めた。人工呼吸器管理をしてい たが，気腫による呼吸状態が増悪した。術前気管支鏡では 損傷部位は確定できなかったが食道や気管の損傷を疑い緊 急手術を行った。術中, 気道・食道を内視鏡で精查, リー クテストも行ったが縱隔気腫の原因部位は同定できなかっ た。経過良好であり, 術後 5 日目 CT にて気腫は顕著に改 善，15日目にリハビリ目的で転院となった。

\section{9. 閉塞性動脈硬化症に対する血管内治療の一工夫} 川崎医科大学 胸部心臓血管外科

鈴木重朋，正木久男，田淵篤 柚木靖弘, 久保陽司, 種本和雄 症例は 80 歳女性. 左下肢間欠性跛行を自覚し, ABI は 0.45 , 血管造影では左外腸骨動脈が閉塞していた。手術は 左総大腿動脈を露出切開し, 3 Fr. Fogarty 血栓摘除用力 テーテルを中枢側へ挿入，赤色血栓を排出した。 ガイドワ イヤーは大動脈まで通過し，血管内超音波で左総腸骨動脈 にも狭窄を認め, Stent 2 個を留置した $($ SMART, $10 \times 60$ $\mathrm{mm}, 8 \times 80 \mathrm{~mm})$. 術後経過は順調で, ABI は0.99に改善し た。

\section{0. 真性遠位弓部大動脈瘤に合併した急性大動脈解離 の 1 手術例}

川崎医科大学 胸部心臟血管外科

甲斐田祐子，濱 中荘平，稲垣英一郎 中山晴輝, 保田紘一郎, 久保陽司 久保裕司, 葉山牧夫, 清水克彦 柚木靖弘, 田淵篤, 中田昌男 正木久男, 種本和雄

76歳男性. 他院で弓部大動脈瘤精査中に突然の胸腹部痛 で急性大動脈解離発症，緊急手術となった。手術は胸骨正 中切開に左第 4 肋間開胸（Trap door 法）を追加し気管分 岐部レベルの末梢側吻合部の視野を確保した。両腋窩動 脈・大腿動脈送血で人工心肺確立.末梢側吻合は open distal 法で脳分離体外循環を確立，体循環停止とした。末 梢側は真腔に step wise で吻合. 術後経過良好で退院した。

\section{1. 肺ヒストプラズマ症の一例}

岡山赤十字病院 外科

黒崎毅史, 森山重治，中原早紀 村岡孝幸, 渡辺啓太郎, 佃 和 憲 高木章司, 池田英二, 平井隆二 辻尚志, 名和清人

患者は63歳男性で，検診にて異常影を指摘されて精査目 的に入院.気管支鏡施行するも確定診断は得られなかった。 画像所見上肺がんの可能性が高く，確定診断もかねて手術 を行った．胸腔鏡補助下右上葉切除術施行．肉眼所見では 肺癌，結核を疑わせたが，永久病理標本にて肺ヒストプラ ズマ症と診断確定した。 


\section{2. マンモトーム生検によって診断された非浸潤性乳 管癌 (DCIS) の 3 例}

岡山大学医学部 · 歯学部附属病院 乳腺 - 内分泌外科 吉 富誠二, 小笠原 豊, 土井原博義

当科では 2006 年 1 月からマンモトーム生検を導入し, 現 在までに25例に対し施行した。このうち 3 例が悪性病変で いずれも DCIS であった. 3 例ともマンモグラフィで石灰 化病変（カテゴリー3-2または 4) を指摘され, 非触知 で，エコーでは病変を描出できなかった。治療法は $\mathrm{Bp}+$ $\mathrm{SNB}$ を 2 例, $\mathrm{Bp}+\mathrm{Ax}$ を 1 例に施行した. マンモトーム生 検は非触知石灰化病変に対して有効な診断法で, 乳癌早期 発見に寄与すると考えられた。

\section{ICG 蛍光造影法を利用したリンパ管静脈吻合}

岡山大学大学院医歯薬学総合研究科 形成再建外科学

森定淳, 杉山成史, 平川久美子

中島美帆, 安岡智之, 山下修二

山田潔, 筒井哲也, 長谷川健二郎 難波祐三郎，木股敬裕

従来, リンパ浮腫に対し外科的治療としてリンパ管静脈 吻合術が行われてきたが，リンパ管を確実に見つける方法 がないことが問題である. 最近，センチネルリンパ節を同 定するために ICG 蛍光造影法が開発された. 特殊な赤外線 カメラを用いてリンパ流を観察出来るようになり，リンパ 管静脈吻合にも応用されるようになった。我々もこれを利 用したリンパ管静脈吻合を行ったので報告する。

\section{4. 食道癌と甲状腺癌同時切除例の検討}

岡山大学大学院医歯薬学総合研究科 消化器 - 腫瘍外科学 ${ }^{\mathrm{a}}$ 岡山市立市民病院 外科 $\mathrm{b}$

藤原康宏 ${ }^{\mathrm{a}}$, 猶本良夫党, 田辺俊介 ${ }^{\mathrm{a}}$ 高岡宗德, 白川靖博 ${ }^{\mathrm{a}}$, 山辻知 樹 ${ }^{\mathrm{a}}$ 小林直哉, 藤原俊義, 松原長秀 ${ }^{\mathrm{a}}$ 岩垣博 巳 $\mathrm{a}$, 松岡順治 ${ }^{\mathrm{a}}$, 羽井佐 実 ${ }^{\mathrm{b}}$ 田中紀 章 ${ }^{\mathrm{a}}$

食道癌に頭澒部癌を重複することは知られているが, 甲 状腺癌を重複した報告は少ない. PET-CT などの診断技術 の進歩に伴い重複癌の発見頻度は高くなると考えられる. 当科では食道癌に甲状腺癌を重複し, 食道癌と同時に切除 し得た 5 症例につき考察した。特に重複癌の頻度の高い食 道癌症例においては CT などの検査と組み合わせ慎重に 術前診断を行うことが重要と考えられた。

\section{G-CSF 産生食道癌の 1 例}

岡山大学大学院医歯薬学総合研究科 消化器 - 腫瘍外科学 ${ }^{\mathrm{a}}$ 岡山市立市民病院 外科 $\mathrm{b}$

高岡宗德 ${ }^{\mathrm{a}}$ 猶本良夫 ${ }^{\mathrm{a}}$, 田辺俊介 ${ }^{\mathrm{a}}$ 藤原康宏 ${ }^{\mathrm{a}}$, 白川靖博 ${ }^{\mathrm{a}}$, 山辻知樹 ${ }^{\mathrm{a}}$ 小林直 哉 $\mathrm{a}$, 藤原俊 義 ${ }^{\mathrm{a}}$, 松原長 秀 ${ }^{\mathrm{a}}$ 岩垣博 巳a, 松岡順治 ${ }^{\mathrm{a}}$, 羽井佐 実 ${ }^{\mathrm{b}}$ 田中紀章 ${ }^{\mathrm{a}}$

比較的稀な G-CSF 産生食道扁平上皮癌を経験したので 報告する。症例は71歳男性, 食物のつかえ感を主訴に上部 消化管内視鏡を施行したところ，食道下部に全周性狭窄を 認め, 生検にて中分化型扁平上皮癌であった。 入院時白血 球数及び血中 G-CSF 濃度の高值を認め, 食道癌に対する 根治的切除後に白血球数 - 血中 G-CSF 濃度とも正常化し た. 摘出組織を用いた免疫染色で, 腫瘍細胞に一致して G-CSF が発現していた。

\section{6. 食道癌化学療法後骨䯣異形成症候群の検討}

岡山大学大学院医歯薬学総合研究科 消化器 $\cdot$ 腫瘍外科学 ${ }^{\mathrm{a}}$ 岡山市立市民病院 外科 $\mathrm{b}$

田辺俊介 ${ }^{\mathrm{a}}$, 猶本良夫 ${ }^{\mathrm{a}}$, 藤原康宏 ${ }^{\mathrm{a}}$ 高岡宗徳 ${ }^{a}$, 白川靖博 ${ }^{a}$, 山辻知樹 ${ }^{a}$ 小林直哉 $\mathrm{a}$, 藤原俊 義, 松原長秀 ${ }^{\mathrm{a}}$ 岩坦博 巳a, 松岡順治 ${ }^{\mathrm{a}}$, 羽井佐 実 ${ }^{\mathrm{b}}$ 田中紀章 ${ }^{\mathrm{a}}$

当科にて経験した食道癌治療症例において，放射線化学 療法後に骨髄異形成症候群（MDS）を発症し，治療誘発性 （二次性）骨髄異形成症候群が疑われた症例を経験した。 平成 7 年〜現在まで食道癌に対し，根治あるいは術後照射 施行した症例534例中 4 例 $(0.75 \%)$ に治療後造血器悪性腫 瘍を認めた。うち 3 例が MDS であった。原発性 MDS の 発症頻度は文献上高い頻度の報告でも 1,000 人あたり 0.75 人程度であり, 食道癌に対する放射線化学療法後の MDS の発症頻度は約 10 倍と考えられた。

\section{Spiegel 腱膜部に発生した $5 \mathrm{~mm}$ ポート孔からの腹 壁痽痕ヘルニア}

倉敷中央病院 外科

古賀睦人, 鶴田淳, 伊藤 雅 小笠原敬三

我々は Spiegel 腱膜部 (傍腹直筋外縁) に腹腔鏡手術術 後の $5 \mathrm{~mm}$ ポート孔から発生したした腹壁痗痕へルニアを経 験した. 腹腔鏡下手術の合併症として, $10 \mathrm{~mm}$ 以上の゚ート で腹壁㓔痕へルニアを来たす報告例は散見される。 $5 \mathrm{~mm}$ ポ ートで腹壁㓔痕へルニアを来たすことはまれであるが，本 
症例では Spiegel 腱膜部という解剖学的特徵に加え, 肥満 という因子が加わり, 発生したと考元, 若干の文献的考察 を加え，報告する。

\section{8. free air を伴い保存的治療にて軽快した腸管囊腫 様気腫症の 1 例}

津山中央病院 外科

北本晃一, 河合毅, 横道直佑 母里淑子, 松本朝子, 松村年久 野中泰幸, 林同輔, 宮島孝直 黒瀬通弘, 徳田直彦

free air を伴ったが保存的に軽快した腸管囊腫様気腫症 の 1 例を経験した. 症例は75歳男性. 肺癌術後にて通院中, 繰り返す上腹部痛あり, 腹単 $\mathrm{X}-\mathrm{P}$ にて小腸壁内ガスを認め 入院. CT にて free air と回腸壁内のガス貯留を認めた. 腹痛は強いが腹膜刺激症状は軽度で，開腹せず保存的に治 療し軽快した。腸管囊腫様気腫症は腸管壁に多発性の含気 性囊胞を形成する比較的まれな疾患であるが，free air を 伴うこともあり, free air を来す疾患の鑑別診断として念 頭に置く必要がある。

\section{9. 画像上診断が困難で長期間経過をみられた早期胆 囊癌の 1 切除例}

津山中央病院 外科

河合 毅, 北本晃一, 横 道直祐

滝内宏樹, 母里淑子, 松本朝子

松村年久, 野中康幸, 林同輔

宮島孝直, 黒瀬通弘, 徳田直彦

画像上診断困難で長期間経過をみられた早期胆囊癌の 1 切除例を経験した。症例は76歳女性. 2000年10月急性胆囊 炎で当院内科入院. PTGBD 造影で胆囊䅡部に腫瘤認め胆 囊癌が疑われたが，胆囊内へパリン洗浄にて腫瘤消失し， 浸潤像も改善したため外来で follow されていた。 その後腫 瘤再発するも無症状で胆汁細胞診，肝門部生検で悪性所見 なく経過観察されていたが，腫瘍増大傾向認め2006年手術 施行. 長期の経過にもかかわらず粘膜内に留まる胆囊癌で あった。

\section{Shock, DIC に陥った超高齢者急性胆囊炎の 2 救 命例}

岡山済生会総合病院外科 救急科

稲葉基高, 繁光 薰, 木村臣一

仁熊健文

高齢化社会を迎え，超高齢者症例を経験することも多く なっている。胆囊炎においても高齢者では典型的な症状を
訴えず,突然重篤化する場合も多く,予備力の低下から DIC や shockにも移行しやすい. shock をきたしている症例で は救命のため超高齢者であっても緊急手術に踏み切る必要 がある，我々は来院時に shock，DIC を来していた重症急 性胆囊炎に対し緊急手術を施行, 術後 PMX - 抗 DIC 療 法・CHDF 等により救命し得た超高齢者症例（症例 $1 ： 83$ 歳，症例 $2 ： 91$ 歳）を経験したので若干の考察を加え報告 する。

\section{CTにて術前診断が可能であった胆囊捻転症の一 例}

岡山市立市民病院 外科

林達朗, 森 雅信, 山野寿久 川崎伸弘, 羽井佐 実, 松前大

濱田英明

症例は85歳の女性，受診前日より右上腹部痛を発症。右 上腹部に約 $5 \mathrm{~cm}$ 大の有痛性の腫瘤を触知した．腹部造影 CTにて胆囊は肝臓の外側に位置して腫大していた。胆囊 粘膜は造影され胆囊䅡部で先細りと索状を呈した。胆囊捻 転症と診断し，緊急手術を行った，抗血小板剂を内服して いるため開腹胆囊摘出術を施行．胆囊は遊走胆囊を呈し反 時計回りに180度捻転していた. 胆囊捻転症は比較的まれな 疾患であるが，造影 CT にて術前診断が可能であった。

\section{2. 膵リンパ上皮囊胞の 1 例}

水島協同病院 外科

多田龍平, 山本明広, 石部洋一

江口孝行

56歳男性. 健診の精査 CT にて膵頭部腫瘤を指摘され た. CEA, CA 19-9 は正常範囲。腹部 CT では長径 $3 \mathrm{~cm}$ 程 度, 境界不明瞭, 辺縁不整な多房性囊胞性腫瘤を認めた。 良性腫瘍が疑われたが悪性も否定できず，膵頭十二指腸切 除術予定にて開腹．腫瘍は膵頭部に約 $4 \mathrm{~cm}$ 大，外見は襄胞 様であった。迅速病理では良性であり, 霊胞壁の切除術を 行い閉腹した。病理検查では膵リンパ上皮囊胞であった。 本疾患は稀な疾患で，悪性腫瘍との鑑別が困難な場合は手 術が必要である。

\section{HALSにて切除した肝 FNH ( focal nodular hyperplasia) の 1 例}

岡山労災病院 外科

$$
\text { 上野 剛, 大村泰之, 河合央 }
$$$$
\text { 間野正之，鹑尾一浩，西英行 }
$$

症例は18歳女性で，右下腹部にかけて存在する $10 \mathrm{~cm}$ 大の FNH と診断された。手術は全身麻酔下に左半側臥位とし, 
吊り上げ併用・低圧気腹で，右下腹部に $7 \mathrm{~cm}$ の小切開をお き術者の左手を挿入し， 3 ポートにて行った。鏡視下用超 音波にて切離線を決定し, 超音波凝固切開装置, LigaSure ${ }^{\circledR}$
にて肝実質の切離を行い, 自動縫合器にて肝静脈・グリソ ン切離を行った。術後経過は良好で第 9 日目に退院となっ た。 